\title{
HUBUNGAN JENIS KELAMIN, INDEKS MASSA TUBUH DAN PERAWATAN WAJAH DENGAN DERAJAT KEPARAHAN ACNE VULGARIS
}

\author{
Fanny Gomarjoyo $^{1}$, Agnes Kartini ${ }^{2}$, M. Khairul Nuryanto ${ }^{3}$ \\ ${ }^{1}$ Program Studi Kedokteran, Fakultas Kedokteran, Universitas Mulawarman \\ ${ }^{2}$ Laboratorium Ilmu Kulit dan Kelamin, Fakultas Kedokteran, Universitas Mulawarman \\ ${ }^{3}$ Laboratorium Ilmu Kesehatan Masyarakat, Fakultas Kedokteran, Universitas Mulawarman \\ Emaii:fannyjoyo@yahoo.co.id
}

\begin{abstract}
Acne vulgaris is one of problem skin disease for adolescents and young adults. Acne vulgaris $(A V)$ is a chronic inflammation of pilosebasea follicles with multifactorial causes and has clinical manifestations such as blackheads papules, pustules, nodules and cysts. Risk factor of acne vulgaris is obesity. Obesity usually happens along with peripheral hyperandrogen and can increase sebum production. Facial care consists of cleaning, moisturizer and sun protector and analyzed relation with severity of acne vulgaris. The purpose of this study was to determine the relationship of gender, body mass index and facial care to severity of acne vulgaris. This study was an observational analytic with cross sectional method and the sampling was chosen by purposive sampling. The minimum sample size was 59 subjects. Data from this study were obtained from measurement of body mass index and diagnostic photos in acne prone subjects. The result of statistical tests showed that there was relationship between sex with the severity of acne vulgaris with $(p=0.014)$ and severity of acne vulgaris having an opportunity 6 times greater in males than females. Body mass index and facial care have no relation to the severity of acne vulgaris.
\end{abstract}

Keywords: Acne vulgaris, Body Mass Index and Facial Care

\section{PENDAHULUAN}

Acne vulgaris (AV) merupakan peradangan kronis folkel pilosebasea dengan penyebab multifactor dan memiliki manifestasi klinis seperti komedo, papul, pustul, nodul serta kista (Wasitatmadja, 2015). Adapun beberapa faktor yang terlibat dalam acne vulgaris seperti hiperkeratinisasi folikel pilosebaseus, produksi sebum yang meningkat, Propionilbacterium acnes dan proses inflamasi (Nurmalina, 2011).

Acne vulgaris adalah salah satu penyakit kulit yang menjadi masalah bagi remaja dan dewasa muda. Di dunia ini diperkirakan terdapat lebih dari 60 juta orang menderita acne, yang didominasi oleh usia remaja dan dewasa muda dengan angka prevalensi sebesar 79-95\%. Acne juga mengenai populasi remaja di Inggrissebanyak 85\% (Smith, 2007). Dalam suatu penelitian yang dilakukan terhadap 1.045 remaja di Singapura, hasilnya diperoleh $88 \%$ memiliki acne vulgaris. Dari jumlah tersebut, sebanyak $51.4 \%$ termasuk acne vulgaris ringan, $40 \%$ acne vulgaris sedang dan $8.6 \%$ acne vulgaris berat. Catatan kelompok studi dermatologi kosmetika Indonesia menunjukkan terdapat $60 \%$ penderita acne vulgaris tahun 2006, dan terdapat $80 \%$ penderita tahun 2007 (Purwaningdyah, 2013).

Acne vulgaris cukup merisaukan dan mengurangi rasa percaya diri serta meningkatkan insiden kecemasan sampai depresi. Umumnya, acne pada perempuan lebih awal daripada laki-laki, karena masa pubertas perempuan umumnya lebih cepat dari pada lakilaki (Perkins, 2018). Acne vulgaris secara umum dimulai pada usia 12-15 tahun, dengan puncak 
tingkat keparahan pada 17-21 tahun, serta terbanyak pada remaja usia 15-18 tahun (Wasitatmadja, 2015).

Acne vulgaris memiliki beberapa faktor risiko, salah satunya obesitas yaitu akumulasi lemak yang berlebih. Pada penelitian sebelumnya yang dilakukan di Taiwan, indeks massa tubuh dengan kategori obesitas merupakan faktor risiko yang signifikan terhadap kejadian acne vulgaris pada anak usia sekolah (Tsai, 2018). Penelitian di Australia menunjukkan bahwa indeks massa tubuh pada laki-laki berumur 18-25 tahun menunjukkan korelasi yang signifikan, tetapi tidak berlaku untuk subjek berumur $<18$ tahun (Smith, 2007). Berdasarkan penelitian di Italia, acne vulgaris tidak berkorelasi positif dengan indeks massa tubuh karena adanya penurunan risiko acne vulgaris pada remaja dengan indeks massa tubuh yang lebih rendah (Borgia, 2018).

Acne vulgaris merupakan salah satu kelainan kulit yang paling sering membutuhkan terapi, meskipun penyakit ini dapat sembuh sendiri.Terdapat berbagai pilihan terapi acne vulgaris, meliputi retinoid topikal, agen microbial topikal dan sistemik, agen hormonal, isotretinoin dan pilihan nonfarmakologis lainnya (Mkele, 2012). penggunaan terapi yang efektif dapat memberikan dampak negatif sehingga memunculkan acne vulgaris.Pengobatan acne vulgaris yang sering digunakan selama lebih dari empat decade adalah kontrasepsi oral kombinasi (Salbaggio, 2010). Perawatan wajah yang lainnya terdiri dari pembersih, pelembab dan tabir surya.Sebagai contoh, mencuci muka dengan sabun secara berlebihan dapat memperberat dan menambah lesi acne (Gray, 2008). Pemakaian pembersih tidak cukup, sehingga harus disertai dengan pelembab untuk menjaga kulit dari kekeringan dan tabir surya untuk melindungi kulit wajah dari paparan langsung sinar ultraviolet.Bahan-bahan kimia yang ada dalam kosmetik secara langsung dapat menyebabkan acne dalam bentuk ringan terutama komedo tertutup dengan beberapa lesi papulopustul di daerah pipi dan dagu (Harahap, 2003). Berdasarkan data di atas, peneliti tertarik untuk melakukan penelitian ini.

\section{METODE PENELITIAN}

Penelitian ini merupakan jenis penelitian observasional analitik dengan pendekatan CrossSectional.Penelitian ini mengambil lokasi di SMKN 1 Samarinda dan dilaksanakan pada Februari 2019. Populasi dalam penelitian ini adalah siswi SMKN 1 Samarinda yang memliki acne vulgaris sebanyak 88 responden. Dalam penelitian ini cara pengambilan sampel dilakukan dengan menggunakan teknik purposive sampling dengan jumlah sampel sebanyak 89 sampel. Sampel akan diambil sesuai dengan kriteria inklusi dan eksklusi. Kriteria Inklusi :

1) Siswi yang menderita acne vulgaris.

2) Siswi yang menggunakan salah produk perawatan wajah seperti pembersih, pelembab dan tabir surya dalam 6 bulan terakhir.

3) Bersedia ikut dalam penelitian dan menandatangani informed consent.

Kriteria eksklusi adalah responden yang tidak mengisi kuesoner dengan lengkap.

Cara pengambilan data menggunakan data primer berupa yang diperoleh dari pengukuran langsung tinggi dan berat badan, kuesioner dan diagnosis oleh dokter spesialis kulit dan kelamin dengan foto tampak depan serta samping.

$\begin{array}{llll}\text { Hasil penelitian disajikan dengan } \\ \text { menggunakan analisis univariat } & \text { dengan } \\ \text { mendefinisikan } & \text { setiap variabel yang diteliti }\end{array}$ secara terpisah dengan cara membuat tabel distribusi dari masing-masing variabel yang meliputi inddeks massa tubuh, perawatan wajah, riwayat keluarga, siklus haid, penggunaan sabun wajah, cleansing milk, sabun wajah, pelembab, tabir surya dan jenis tabir surya. Analisis bivariat dilakukan dengan menggunakan uji $c h i$ 
square untuk mengetahui hubungan antara jenis kelamin, indeks massa tubuh dan perawatan wajah dengan derajat keparahan acne vulgaris. Hubungan kedua variabel dianggap bermakna jika nilai $\mathrm{p}<0,05$ dan tidak bermakna jika nilai $\mathrm{p}>0,05$.

Pengolahan data dilakukan dengan 3 tahapan, yaitu input data, edit data dan tabulasi data menggunakan Microsoft Excel 2010 dan SPSS Statistic Versi 24 bit. Penyajian data dilakukan dalam bentuk narasi,tabel dan/atau diagram, frekuensi dan persentase.

\section{HASIL DAN PEMBAHASAN}

Penelitian ini dilakukan pada remaja wanita dengan rentang usia 14-16 tahun yang diwakili oleh siswi sekolah menengah atas. Adapun distribusi responden yang menderita acne vulgaris derajat berat sebanyak 6 responden $(6,8 \%)$ dan derajat ringan sebanyak 82 responden $(93,2 \%)$.

Tabel 1. Gambaran Derajat Keparahan

\begin{tabular}{ccc}
\multicolumn{3}{c}{ AcneVulgaris } \\
\hline $\begin{array}{c}\text { Derajat } \\
\text { Keparahan }\end{array}$ & $\begin{array}{c}\text { Jumlah } \\
(\mathbf{n}=\mathbf{8 8})\end{array}$ & Persentase \\
Acne Vulgaris & & \\
\hline Berat & 6 & 6,8 \\
Ringan & 82 & 93,2 \\
\hline
\end{tabular}

Responden yang memiliki indeks massa tubuh berlebih atau obesitas adalah 14 responden $(15,9 \%)$ dan indeks massa tubuh kurus atau normal sebanyak 74 responden $(84,09 \%)$ seperti pada tabel 2 .

Tabel 2. Gambaran Distribusi Indeks Massa Tubuh

\begin{tabular}{ccc}
\hline Klasifikasi IMT & $\begin{array}{c}\text { Jumlah } \\
(\mathbf{n = 8 8})\end{array}$ & Persentase \\
\hline BB & 14 & 15,9 \\
$\begin{array}{c}\text { berlebih/obesitas } \\
\text { BB kurus/normal }\end{array}$ & 74 & 84,09 \\
\hline
\end{tabular}

Distribusi perawatan wajah responden adalah $76(86.4 \%)$ melakukan perawatan wajah dan $12(13.6 \%)$ tidak melakukan perawatan wajah seperti pada tabel 5.4.

Tabel 3. Gambaran Distribusi Perawatan Wajah

\begin{tabular}{ccc}
\hline $\begin{array}{c}\text { Perawatan } \\
\text { Wajah }\end{array}$ & $\begin{array}{c}\text { Jumlah } \\
(\mathbf{n = 8 8})\end{array}$ & Persentase \\
\hline Tidak & 12 & 13,6 \\
Ya & 76 & 86,4 \\
\hline
\end{tabular}

Distribusi riwayat keluarga responden adalah $64(72.7 \%)$ memiliki riwayat menderita acne vulgaris dan 24 (27.3\%) tidak memiliki riwayat menderita acne vulgaris seperti pada tabel 5.5.

Tabel 4. Gambaran Distribusi Genetik

\begin{tabular}{ccc}
\hline Genetik & $\begin{array}{c}\text { Jumlah } \\
(\mathbf{n}=\mathbf{8 8})\end{array}$ & Persentase \\
\hline Ya & 64 & 72.7 \\
Tidak & 24 & 27.3 \\
\hline
\end{tabular}

Distribusi frekuensi pemakaian bedak responden adalah $48(54,54 \%)$ sering memakai bedak, 21 (23.86\%) kadang-kadang memakai bedak dan 19 (21,6\%) tidak memakai bedak seperti pada tabel 5 .

Tabel 5. Gambaran Distribusi Frekuensi Pemakaian Bedak

\begin{tabular}{ccc}
\hline $\begin{array}{c}\text { Pemakaian } \\
\text { Bedak }\end{array}$ & $\begin{array}{c}\text { Jumlah } \\
(\mathbf{n = 8 8})\end{array}$ & Persentase \\
\hline Sering & 48 & 54,54 \\
Kadang & 21 & 23,86 \\
Tidak & 19 & 21,6 \\
\hline
\end{tabular}

Distribusi jenis bedak pada responden adalah 60 (86,96\%) memakai bedak tabur dan 9 $(13,04 \%)$ memakai bedak padat seperti pada tabel 6.

Tabel 6. Gambaran Distribusi Jenis Bedak

\begin{tabular}{ccc}
\hline Jenis Bedak & $\begin{array}{c}\text { Jumlah } \\
(\mathbf{n = 6 9 )}\end{array}$ & Persentase \\
\hline Padat & 9 & 13,04 \\
Tabur & 60 & 86,96 \\
\hline
\end{tabular}

Distribusi pemakaian sabun wajah responden adalah 66 (75\%) memakai sabun 
wajah dan 22 (25\%) tidak memakai sabun wajah seperti pada tabel 7 .

Tabel 7. Gambaran Distribusi Pemakaian

\begin{tabular}{ccc}
\multicolumn{3}{c}{ Sabun Wajah } \\
\hline SabunWajah & $\begin{array}{c}\text { Jumlah } \\
(\mathbf{n = 8 8})\end{array}$ & Persentase \\
\hline Tidak & 22 & 25 \\
Ya & 66 & 75 \\
\hline
\end{tabular}

Distribusi pemakaian cleansingmilk responden adalah $16 \quad(18.2 \%)$ memakai cleansing milk dan 72 (81.8\%) tidak memakai cleansing milk seperti pada tabel 8.

Tabel 8. Gambaran Distribusi Pemakaian Cleansing Milk

\begin{tabular}{ccc}
\multicolumn{3}{c}{ Cleansing Milk } \\
\hline $\begin{array}{c}\text { Cleansing } \\
\text { Milk }\end{array}$ & $\begin{array}{c}\text { Jumlah } \\
(\mathbf{n = 8 8})\end{array}$ & Persentase \\
\hline Tidak & 72 & 81,8 \\
Ya & 16 & 18,2 \\
\hline
\end{tabular}

Distribusi pemakaian pelembab responden adalah 36 (40.9\%) memakaipelembab dan 52 (59.1\%) tidak memakai pelembabseperti pada tabel 9.

Tabel 9. Gambaran Distribusi

PemakaianPelembab

\begin{tabular}{ccc}
\hline Pelembab & $\begin{array}{c}\text { Jumlah } \\
(\mathbf{n = 8 8})\end{array}$ & Persentase \\
\hline Tidak & 52 & 59,1 \\
Ya & 36 & 40,9 \\
\hline
\end{tabular}

Distribusi pemakaian tabir surya responden adalah 30 (34.1\%) memakaitabir surya dan 58 (65.9\%) tidak memakai tabir suryaseperti pada tabel 10 .

Tabel 10. Gambaran Distribusi PemakaianTabir Surya

\begin{tabular}{ccc}
\hline Tabir Surya & $\begin{array}{c}\text { Jumlah } \\
(\mathbf{n = 8 8})\end{array}$ & Persentase \\
\hline Tidak & 58 & 65,9 \\
Ya & 30 & 34,1 \\
\hline
\end{tabular}

Distribusi jenis tabir surya responden adalah 19 (63,33\%) memakaikrim dan 11 $(36,67 \%)$ memakai gel seperti pada tabel 11 .

Tabel 11. Gambaran Distribusi Jenis Tabir Surya

\begin{tabular}{ccc}
\hline $\begin{array}{c}\text { Jenis Tabir } \\
\text { Surya }\end{array}$ & $\begin{array}{c}\text { Jumlah } \\
(\mathbf{n}=\mathbf{3 0})\end{array}$ & Persentase \\
\hline Krim & 19 & 63,33 \\
Gel & 11 & 36,67 \\
\hline
\end{tabular}

Berdasarkan data univariat yang sudah dikumpulkan, peneliti mengambil indeks massa tubuh dan perawatan wajah sebagai variabel dalam penelitian. Berikut ini merupakan hasil tabulasi silang antara indeks massa tubuh dengan derajat keparahan acne vulgaris.

Tabel 12. Hasil Tabulasi Silang Indeks Massa Tubuh dengan Derajat Keparahan Acne vulgaris

\begin{tabular}{|c|c|c|c|c|c|c|c|}
\hline \multirow[t]{3}{*}{$\begin{array}{c}\text { Indeks } \\
\text { Massa } \\
\text { Tubuh }\end{array}$} & \multicolumn{4}{|c|}{$\begin{array}{c}\text { Derajat } \\
\text { Keparahan }\end{array}$} & \multirow{3}{*}{$\begin{array}{c}\text { Preva } \\
\text { lence } \\
\text { Ratio } \\
\text { (PR) }\end{array}$} & \multirow{3}{*}{$\begin{array}{c}95 \% \\
\text { Confi } \\
\text { dence } \\
\text { Interv } \\
\quad \text { al }\end{array}$} & \multirow[t]{3}{*}{$\mathbf{P}$} \\
\hline & \multicolumn{2}{|c|}{ Berat } & \multicolumn{2}{|c|}{$\begin{array}{c}\text { Ringa } \\
\text { n }\end{array}$} & & & \\
\hline & $\mathbf{N}$ & $\%$ & $\mathbf{N}$ & $\%$ & & & \\
\hline Berlebih/ & 2 & 14 & 1 & 85 & 2,643 & 0,48 & 0 \\
\hline Obesitas & 4 & ,2 & 2 &, 7 & & 17,72 & 22 \\
\hline \multirow{4}{*}{$\begin{array}{c}\text { Kurus/N } \\
\text { ormal }\end{array}$} & & 9 & 7 & 1 & & 4 & 7 \\
\hline & & 5 , & 0 & 94 & & & \\
\hline & & 41 & & ,5 & & & \\
\hline & & & & 9 & & & \\
\hline
\end{tabular}

Pengolahan data yang dilakukan dalam analisis hubungan indeks massa tubuh dengan derajat keparahan acne vulgaris diperoleh acne vulgaris ringan maupun berat terjadi pada responden dengan indeks massa tubuh kurus hingga normal seperti pada tabel 12. Secara statistik pola hubungan tersebut diuji menggunakan uji analisis dengan hasilnya berupa nilai signifikansi sebesar 0.227 ( $p>0,05$ ). Sehingga dapat diartikan bahwa hipotesis yang 
menyatakan hubungan antara indeks massa tubuh dengan derajat keparahan acne vulgaris tidak dapat diterima.

Berikut ini merupakan hasil tabulasi silang antara perawatan wajah dengan derajat keparahan acne vulgaris.

Tabel 13. Hasil Tabulasi Silang Perawatan Wajah dengan Derajat Keparahan Acne vulgaris

\begin{tabular}{|c|c|c|c|c|c|c|c|}
\hline \multirow{3}{*}{$\begin{array}{c}\text { Peraw } \\
\text { atan } \\
\text { Waja } \\
\text { h }\end{array}$} & \multicolumn{4}{|c|}{$\begin{array}{c}\text { Derajat } \\
\text { Keparahan } \\
\text { Acne Vulgaris }\end{array}$} & \multirow{3}{*}{$\begin{array}{c}\text { Preval } \\
\text { ence } \\
\text { Ratio } \\
\text { (PR) }\end{array}$} & \multirow{3}{*}{$\begin{array}{c}95 \% \\
\text { Confid } \\
\text { ence } \\
\text { Interva } \\
l\end{array}$} & \multirow[t]{3}{*}{$\mathbf{P}$} \\
\hline & \multicolumn{2}{|c|}{ Berat } & \multicolumn{2}{|c|}{$\begin{array}{c}\text { Ringa } \\
\mathbf{n}\end{array}$} & & & \\
\hline & $\mathbf{N}$ & $\%$ & $\mathbf{N}$ & $\%$ & & & \\
\hline \multirow[t]{2}{*}{ Tidak } & 2 & 16 , & 1 & 83 , & 3.6 & 0,582 & 0,1 \\
\hline & & 67 & 0 & 33 & & $-22,2$ & 45 \\
\hline \multirow[t]{2}{*}{$\mathrm{Ya}$} & 4 & 5,2 & 7 & 94 , & & & \\
\hline & & 7 & 2 & 73 & & & \\
\hline
\end{tabular}

Pengolahan data yang dilakukan dalam analisis hubungan perawatan wajah dengan derajat keparahan acne vulgaris diperoleh acne vulgaris ringan maupun berat terjadi pada responden yang melakukan perawatan wajah. Secara statistik pola hubungan tersebut diuji menggunakan uji analisis dengan hasilnya berupa nilai signifikansi sebesar 0.145 ( $p>0,05)$. Sehingga dapat diartikan bahwa hipotesis yang menyatakan hubungan antara perawatan wajah dengan derajat keparahan acne vulgaris tidak dapat diterima.

Responden yang memiliki kriteria inklusi adalah 88 perempuan yang berusia 14-16 tahun dan disertai derajat keparahan acne vulgaris yang berbeda. Hal ini sesuai dengan kepustakaan yang menyatakan bahwa puncak insiden acne vulgaris mengenai remaja dengan tingkat keparahan bervariasi dijumpai pada usia 14-17 tahun (Klaus, 2005). Androgen mengontrol pertumbuhan kelenjar sebasea yang aktif saat pubertas dan akan memproduksi sebum. Peningkatan produksi sebum berkaitan dengan kejadian acne vulgaris dan berkembangnya lesi pada acne vulgari seperti lesi non inflamasi (komedo tertutup dan terbuka) dan lesi inflamasi (papul, nodul, pustul dan kista). ${ }^{13}$ Hormon androgen menyebabkan peningkatan ukuran kelenjar sebasea, menstimulasi produksi sebum, serta proliferasi keratinosit pada saluran kelenjar sebasea. Ketidakseimbangan antara produksi dan kapasitas sekresi sebum akan menyebabkan sumbatan sebum pada muara folikel rambut dan membentuk mikrokomedo. Mikrokomedo berisi keratin, sebum dan bakteri akan membesar dan rupture (Tahir, 2010)

Keadaan hiperandrogenemia berhubungan dengan ketidakteraturan siklus menstruasi, hirsutisme dan kejadian acne vulgaris. Hiperandrogenemia juga merupakan penanda terjadinya polycystic ovarian syndrome (PCOS) pada remaja (West, 2014). Pada penelitian ini tidak dilakukan screening mengenai hiperandrogenemia sehingga kejadian acne vulgaris dengan ketidakteraturan siklus menstruasi memungkinkan terjadi pada remaja dengan kelebihan hormone androgen.

Salah satu faktor risiko yang dapat menyebabkan acne vulgaris adalah obesitas. Obesitas yaitu akumulasi lemak abnormal yang dapat diukur dengan indeks massa tubuh. Hasil penelitian sebelumnya, diketahui berat badan berlebih hingga obesitas memiliki korelasi positif dengan kadar insulin. Hiperinsulinemia akan meningkatkan IGF-1 (Insulin Growth Factor-1) yang menyebabkan terjadinya acne vulgaris melalui peningkatan proses keratinisasi pada folikel pilosebasea dan stimulasi produksi hormon androgen sehingga produksi sebum berlebih. Selain itu, peningkatan insulin dan IGF-1 dapat menghambat hati untuk mensintesis Sex Hormone Binding Protein (SHBG) sehingga kadar hormon androgen terhadap jaringan akan meningkat drastic (Smith, 2007).

Hubungan indeks massa tubuh dengan derajat keparahan acne vulgaris dalam penelitian ini didapatkan tidak berhubungan. Hasil tersebut sesuai dengan penelitian Lajevardi (2014) yang mengatakan bahwa kejadian acne vulgaris 
derajat sedang dan berat lebih sedikit terjadi pada pasien underweight (IMT<18,5) dan menunjukkan tidak ada hubungan yang signifikan antara derajat keparahan acne vulgaris dengan indeks massa tubuh $(\mathrm{p}=0,086)$ (Lajevardi, 2014). Hal ini juga sesuai dengan penelitian yang dilakukan Astutiningsih (2014) yang menyatakan bahwa tidak terdapat hubungan antara indeks massa tubuh dan acne vulgaris di SMA Negeri 3 Klaten (Astutiningsih, 2014). Penelitian yang dilakukan oleh Ninggar (2014) juga menyatakan bahwa terdapat korelasi lemah yang bermakna antara indeks massa tubuh dengan derajat keparahan acne vulgaris (Ninggar, 2014). Menurut Kaymak (2007) terdapat korelasi positif antara kadar lemak dalam tubuh dengan derajat keparahan acne vulgaris (Kaymak, 2007).

Kemungkinan terdapat perbedaan metabolisme androgen pada sebosit, keratinosit dan sel papila dermal.Ketiga sel ini distimulasi oleh androgen dan memiliki kemampuan untuk mengubah testosteron menjadi bentuknya yang lebih poten yaitu $5 \alpha$-dihidrotestosteron. Sehingga dalam mengendalikan homeostasis androgen pada kulit, testosteron dimetabolisme menjadi metabolit yang kurang aktif oleh tiga enzim yaitu enzim 17 $\beta$-dehidrogenase mengubah testosteron menjadi androstenidion, enzim $5 \alpha$-reduktase mengubah androstenidion menjadi $5 \alpha$-androstenidion dan enzim $3 \alpha$ hidroksisteroid dehidrogenase mengubah $5 \alpha$ androstenidion menjadi androsteron kembali. ${ }^{19}$ Perbedaan aktivitas enzim antar individual dapat mempengaruhi kadar androgen pada sebosit dan keratinosit, sehingga menyebabkan ketiadaan hubungan acne vulgaris dengan keadaan hiperandrogen yang digambarkan melalui indeks massa tubuh (Borgia, 2018).

Penelitian yang dilakukan Lu (2017) menunjukkan bahwa obesitas/berat badan berlebih pada wanita usia 18-25 tahun dengan acne vulgaris derajat berat dan keluarga yang memiliki riwayat metabolic disorder (obesitas, hipertensi dan diabetes melitus) menjadi faktor risiko pasien acne vulgaris di China. Androgen, insulin, growth hormone dan insulin like growth factor ditemukan meningkat pada pasien obesitas dan memicu aktivitas dari kelenjar sebaseus serta mempengaruhi derajat keparahan acne vulgaris (Lu, 2017). Berdasarkan penelitian yang dilakukan oleh Kabau (2012), penyebab pasti timbulnya acne vulgaris sampai saat ini belum diketahui secara jelas, tetapi sudah pasti disebabkan oleh multifaktorial, baik yang berasal dari luar (eksogen) maupun dari dalam (endogen) yaitu faktor genetik, hormonal, makanan (diet), kosmetik, infeksi dan trauma serta kondisi kulit (Kabau, 2012). Akan tetapi, hasil penelitian ini tidak sesuai dengan penelitian yang dilakukan oleh (Pranitasari, 2011) yang menyatakan bahwa terdapat hubungan antara indeks massa tubuh dengan derajat keparahan acne vulgaris (Pranitasari, 2011). Perbedaan hasil ini bisa disebabkan faktor perancu yang belum bisa dikendalikan peneliti.

Faktor lainnya yang dapat mempengaruhi timbulnya acne vulgaris adalah perawatan wajah.Perawatan wajah merupakan tindakan mempertahankan kelembaban yang adekuat untuk menjaga integritas stratum korneum (Tony, 2010). Setelah dilakukan uji statistik dalam penelitian ini, tidak terdapat hubungan antara perawatan wajah dengan derajat keparahan acne vulgaris.Hal ini sesuai dengan penelitian yang dilakukan Rahmawati (2012) yang menyatakan bahwa tidak ada hubungan perawatan wajah dengan derajat keparahan acne vulgaris.Acne umumnya disebabkan oleh perubahan hormon dan peningkatan produksi sebum yang berlebihan. Akan tetapi, penggunaan kosmetik yang tidak sesuai kondisi kulit dapat menjadi salah satu faktor risiko terjadinya acne vulgaris (Rahmawati, 2012).

Dalam menjaga kulit yang sehat dan pencegahan dari komplikasi diperlukan produk 
kosmetik yang berkualitas. Prinsip dari perawatan wajah pada umumnya meliputi pembersih, pelembab dan tabir surya. ${ }^{10}$ Selain itu penggunaan produk perawatan wajah harus disesuaikan dengan kondisi kulit misalnya kulit normal, kering, berminyak dan campuran (Legiawati,2010).

Pembersih wajah berfungsi untuk menghilangkan debu, sebum, mikroorganisme dan mengelupas lapisan kulit mati.Adapun bahan aktif yang terkandung dalam pembersih yaitu surfaktan. Surfaktan mengandung antimikroba, humektan (gliserin) dan oklusif (parafin) (Surber, 2016). Surfaktan memiliki kadar pH yang tinggi sehingga dapat menyebabkan pembengkakan dari stratum korneum. Hal ini disebabkan terjadinya penetrasi yang lebih dalam pada kulit sehingga mengakibatkan iritasi dan alergi.Sabun wajah juga mengikat protein dari stratum korneum dan menyebabkan kulit mengalami hiperhidrasi sehingga kulit tampak kering.Hal ini menjelaskan menurunnya hidrasi dan elastisitas pada wajah karena sabun. Selain sabun wajah, pembersih lainnya yaitu susu pembersih (cleansing milk).Susu pembersih mengandung air dan campuran minyak seperti minyak biji wijen, minyak zaitun dan minyak bunga matahari.Pembersih ini dapat digunakan untuk kulit normal hingga kering (Draelos, 2017). Kondisi kulit responden yang diteliti yaitu kering hingga normal. Data yang diperoleh menunjukkan bahwa responden lebih banyak menggunakan sabun wajah dibanding susu pembersih. Hal ini menjadi salah satu pemicu terjadinya acne vulgaris karena adanya kandungan surfaktan dalam sabun wajah yang mampu mengiritasi kulit (Del Rosso, 2013).

Dari penelitian diperoleh bahwa frekuensi pemakaian bedak sering dengan jenis bedak tabur. Apabila sampel memiliki masalah kulit seperti acne vulgaris ringan dan diperparah dengan pemakaian bedak yang sering tanpa menjaga kebersihan wajah, hal ini menjadi salah satu pemicu timbulnya inflamasi pada acne vulgaris (Del Rosso, 2013). Dari penelitian juga diperoleh penggunaan pelembab sangat rendah pada siswa/i SMKN 1 sekitar 36 dari 88 sampel. Fungsi dasar dari pemakaian pelembab adalah menjaga kehalusan dan hidrasi kulit serta mengurangi penguapan yang berlebihan.Hal ini dapat menjelaskan jika pemakaian pelembab yang rendah dapat membuat kulit kering semakin mengalami iritasi sehingga dapat memicu timbulnya acne vulgaris ringan maupun berat (Leffell, 2000). Produk perawatan wajah lainnya adalah tabir surya.Tabir surya berfungsi melindungi kulit dari pajanan sinar ultraviolet (UV) secara langsung (Baumann, 2009). Penggunaan tabir surya terbilang cukup rendah yaitu 30 dari 88 responden.Adapun jenis tabir surya yang paling banyak dipakai yaitu krim.Beberapa tabir surya dapat menyebabkan erupsi seperti acne vulgaris sehingga sangat dianjurkan untuk menggunakan gel atau lotion yang tidak komedogenik. Efek samping yang dapat timbul dari pemakaian tabir surya yang tidak sesuai dengan kulit yaitu iritasi dan alergi (Guitera, 2017).

Bahan yang sering menyebabkan acne terdapat pada produk kosmetik seperti bedak dasar(foundation), pelembab(moisturizer) dan tabir surya.Adapun bahan-bahan yang terkandung didalamnya seperti lanolin, petrolatum, minyak tumbuh-tumbuhan dan bahan-bahan kimia murni (butilstearat, laurilalkohol, dan bahan pewarna dan asam oleic (Siregar, 2005). Penyebab timbulnya acne vulgaris yaitu unsur minyak yang berlebih pada produk kosmetik. Minyak akan bertindak seperti minyak alami dan bisa menyumbat poripori. Adanya zat pewarna dapat memperparah timbulnya acne.Bahan pewarna yang terdapat dalam kosmetik seperti pewarna hijau, kuning dan merah. Masing-masing warna memiliki fungsi dan waktu pemakaian yang berbeda misalnya pewarna merah pada kosmetik dapat digunakan dengan kadar maksimal 3\% dan 
pemakaian dalam waktu singkat (Harper, 2004).

Bahan-bahan kimia yang ada dalam kosmetik dapat langsung menyebabkan acne ringan terutama komedo tertutup dengan lesi papulo pustul di daerah wajah.Terjadinya acneakibat penggunaan kosmetik sering dikenal dengan istilah "AcneCosmetics" (Draelos, 2006). Acne lebih banyak ditemukan pada daerah dagu dan pipi,dibandingkan dengan daerah dahi. Awalnya berupa benjolan keputihan dan kecilyang lebih terlihat saat kulit ditarik atau diregangkan, namun lesi dapat terlihat kemerahan.Acne kosmetik lebih jarang menimbulkanbekasluka,tetapibisabertahanselam abertahun- tahun sebagai akibat daripenggunaan kosmetik secaraterus-menerus (Nguyen, 2018).

\section{SIMPULAN}

Acne vulgaris lebih banyak terjadi pada perempuan dengan derajat keparahan yang berbeda. Berdasarkan hasil penelitian tidak terdapat hubungan antara indeks massa tubuh dan perawatan wajah dengan derajat keparahan acne vulgaris.

\section{SARAN}

1. Perlu diberikan edukasi yang baik mengenai penggunaan kosmetik kepada siswa/i SMKN 1 Samarinda agar dapat mengetahui dan melakukan perawatan wajah yang benar sehingga dapat mencegah dan mengurangi acne vulgaris.

2. Dalam melakukan diagnostik sebaiknya langsung diamati oleh dokter spesialis kulit agar terlihat lebih jelas efloresensinya.

3. Perlu penelitian lebih lanjut dengan metode lain seperti cohort untuk melihat hubungan jenis kelamin, indeks massa tubuh dan perawatan wajah dengan derajat keparahan acne vulgaris.

\section{DAFTAR PUSTAKA}

Astutiningsih S. Hubungan Antara Indeks Massa Tubuh (IMT) Dengan Timbulnya Akne Vulgaris Pada Siswa-Siswi SMA Negeri 3 Klaten.2014.

Baumann L., Avashia N., \& Castanedo M. P. Sunscreen. Cosmetics Dermatology: Principles and Practice, 2009: p.245-254.

Borgia F., Cannava S., \& Guarneri F. Correlation between Endocrinological Parameters and Acne Severity in Adult Women. Retrieved October 5, 2018, from Acta

Derm Venereol:http://www.ncbi.nlm.nih.gov/pub med/15202836.2004.

Del Rosso J. Q. Role of Skin Care as an IntegraL Component in the Management of Acne Vulgaris. $J$ Clin Aesthet Dermatol.2013:p. 19-27.

Draelos Z. D. The science behind skin care: Cleansers. Journal of Cosmetic Dermatology.2017(17), p. 8-14.

Draelos Z.,\& Dinardo J. A Re-evaluation of Comedogenicity Concept. Retrieved September 29, 2018, from Journal of The American Academy of Dermatology.2006:54(3): http://www.pdfs.semanticscholar.org/fee9/7 be6fedac72eaf02762db962428b2a28b6b3.p df

Fritsch M., Orfanos C., \& Zoubolis C. Sebocytes are the key regulators of androgen homeostasis in human skin. $J$ Invest Dermatology.2001.(116), p. 793-800

Gray J. Skin Care 2nd Ed. New York: Macmillan Press Ltd. 2008.

Guitera P. A to Z of Skin: Sun Protection and Sunscreens. Australasian College of Dermatologists.2017:p.1-8. 
Harahap M. Akne Vulgaris. In Buku Ilmu Penyakit Kulit Edisi Pertama.Jakarta: Hipokrates. 2008.

Harper J. An update on the pathogenesis and management of acne vulgaris. J Am Acad Dermatol.2004: 51(1), p. 536-8.

Kabau S. Hubungan antara pemakaian jenis kosmetik dengan kejadian acne vulgaris. 2012 .

Kaymak Y. Dietary glycemic index and glucose, insulin, insulin-like Growth Factor-1 insulin-like growth factor binding protein 3 and leptin levels in patient with acne. J.am Acad Dermatol 2007: 57(5), 819-23.

Klaus W, Richard A, Dick S. Fitz Patrick's Color Atlas and Sinopsis of Clinical Dermatology. New York: Medical Publishing Division. 2005.

Lajevardi, V., Ghodsi , S., Daneshpazhooh, M., Kazemi, H., Aryanian, Z., \& Goodarzi, A. The relationship between body mass index and the severity of acne. Iran $J$ Dermatol.2014: 17(1), 13-7.

Leffell D. J. Dreams in a Bottle: Caring for Your SKin.2000:p.76-80.

Legiawati L. Perawatan Kulit pada Akne. Medicinal Jurnal Kedokteran Indonesia.2010:p. 17-19.

Lu L., Lai H., Pan Z., Wu Z., Chen W., \& Ju Q. Obese/overweight and the risk of acne vulgaris in Chinese adolescents and young adults. Hongkong J Derm Venereol.2017 (25),p. 2-5.

Mkele G. An Overview of Treatment Options for Acne Vulgaris. S Afr Pharm J. 2012; $79(10): 32-34$
Nguyen S., Dang T.,\& Maibach H. Comedogenicity: some cosmetics ingredients/vehicles. 2007. Retrieved September 20, 2018, from Cutaneous and Ocular Toxicology: http://www.ncbi.nlm.nih.gov/pubmed/1805 8303

Ninggar G. Korelasi antara indeks massa tubuh dengan derajat keparahan akne pada penderita akne vulgaris. 2014.

Nurmalina, R. Jurus Ampuh Menaklukan Jerawat. Jakarta: PT.Elex Media Komputindo; 2011.

Perkins, A., Cheng, C., Miyamoto, K., \& Kimbal, A. Comparison of the Epidemiology of Acne Vulgaris Among Caucasian, Asian, Continental Indian and African American Women. Retrieved September 15, 2018, from Journal of European Academy of Dermatology and Venereology: http://www.ncbi.nlm.nih.gov/pubmed/2110 $\underline{8671.2011}$

Pranitasari A. R. Hubungan Indeks Massa Tubuh dengan Akne Vulgaris. Surakarta.2011.

Purwaningdyah, R.,\& Nelva,K. Profil Penderita Acne Vulgaris pada Siswa-siswi di SMA Shaifiyatul Amaliyah Medan.E-Journal FK USU.2013.

Rahmawati D. Hubungan Perawatan Kulit Wajah dengan Timbulnya Akne Vulgaris. 2012.

Salvaggio HL, Zaenglein AL. Examining the Use of Oral Contraceptives in the Management of Acne. International Journal of Women's Health. 2010;2:69-76 
Siregar R. Akne Vulgaris. In C. Wijaya, \& P. Anugerah, Atlas Berwarna Saripati Penyakit Kulit.2005. Cetakan III (pp. 209214). Jakarta: EGC.

Smith, R.N., Anna, B., \& George, A.V. A Low Glycemic Loud Diet, Improves Symptoms in Acne Vulgaris Patients: a randomized controlled trial.2007: p.107-115.

Surber, C., \& Kottner, J. Skin Care Products: What do they promise, wahat do they deliver. Journal of Tissue Viability.2016.

Tahir C.M. Pathogenesis of Acne Vulgaris: Simplified-A Review. Journal of Pakistan Association Dermatologists. 2010;20:p.9397.

Tony B., \& Stephen B. Acne Dermatology. UK: Wiley-Blackwell.2010.
Tsai, M., \& Chen, Y. Higher Body Mass Index Is A Significant Risk Factor for Acne Formation in School Children. Retrieved September 22, 2018, from Eur J Dermartology:http://www.cidjournal.com/a rticle/S0738-081X(17)30161-X/pdf. 2006.

Wasitatmadja, S.M. Akne, Akneiformis, Rosasea, Rinofima dalam A. Djuanda, M. Hamzah\&Aisah, Ilmu Kulit dan Kelamin;2015.

West S., Lashen H., Bloigu A., Frank., Puukka., Ruokonen A., Jarvelin., Tapanainen., Morin. Irregular Menstruation and Hyperandrogenaemia in Adolescents are Associated with Polycystic Ovary Syndrome and Infertility in Later Life: Northern Finland Birth Cohort 1986 study. Human Reproduction. 2014;29(10): p. 2339-2351 